\title{
A communication-focused curriculum for dental students - an experiential training approach
}

\author{
Simone Alvarez ${ }^{*}$ (D) and Jobst-Hendrik Schultz
}

\begin{abstract}
Background: Successful interaction and communication with patients is as vital for dentists as it is for physicians. Therefore, the aim of this study was the development and evaluation of an interactive, experiential training curriculum with an emphasis on communication for dual degree seekers of medicine and dentistry.

Methods: A pre-clinical course with an emphasis in physician/dentist-patient communication and interaction was adapted by a team of subject experts based largely on the propositions of Experiential Learning Theory. After attending the course, dental students $(N=81)$ rated the course on a Likert- style scale and answered two open questions.

Results: Students found the interactive course curriculum to be very helpful and vital. Many students reported that their initial interest in the course was mainly because it is a dual degree requirement, but later on rated the course as highly important in terms of later physician/dentist-patient interaction. One aspect of the curriculum course participants regarded as very important, yet neglected during dental studies, was (self-) perception.

Conclusion: In the view of dental students, the rigorous structure of the pre-clinical dental curriculum does not allow for time spent on topics such as (self-) perception and awareness, but training one's ability to self-reflect and think critically about one's own actions, conduct or position can aid with advanced medical and dental studies and practices later on. Experiential courses with an emphasis on patient-physician/dentist communication should be offered early on during pre-clinical medical and dental studies as a regular part of the curriculum.
\end{abstract}

Keywords: Experiential learning, Self-awareness, Dental studies, Curriculum development, Communication

\section{Background}

Effective physician-patient communication skills are as important to medical care as clinical expertise $[1,2]$. The same is true for dentist-patient communication [3-7]. It is known that good physician/dentist-patient communication can lead to a reduction in patient anxiety, and increase factors such as patient satisfaction and adherence to healthy behaviors $[8,9]$.

Thus, successful physician/dentist-patient communication is increasingly becoming a central learning objective at medical schools in Germany. Competency frameworks such as the German National Competence-based Learning Objective Catalogue for Undergraduate Medical Education (NKLM) and the German National Competence-

\footnotetext{
* Correspondence: simone.alvarez@med.uni-heidelberg.de Department of Internal Medicine and Psychosomatics, University Hospital Heidelberg, Heidelberg, Germany
}

(c) The Author(s). 2018 Open Access This article is distributed under the terms of the Creative Commons Attribution 4.0 International License (http://creativecommons.org/licenses/by/4.0/), which permits unrestricted use, distribution, and reproduction in any medium, provided you give appropriate credit to the original author(s) and the source, provide a link to the Creative Commons license, and indicate if changes were made. The Creative Commons Public Domain Dedication waiver (http://creativecommons.org/publicdomain/zero/1.0/) applies to the data made available in this article, unless otherwise stated.

based Learning Objective Catalogue for Undergraduate Dental Education (NKLZ) have been designed to ensure quality standards in regard to medical and dental education. Within this framework, communication is described as a main competency [10]. To ensure the necessary time to practice skills, many schools have established courses with an emphasis on communication [6,11-13].

At the Medical Faculty of Ruprecht Karls University Heidelberg, Germany, medical students take part in a longitudinal communication training that also encompasses training with simulated patients [14]. From the very first semester onward during the pre-clinical phase up until the end of the clinical phase of studies, students are required to attend courses, seminars and tutorials with a focus on physician-patient communication. However, communication training for dental students usually does not start until the clinical phase of studies. One 
opportunity for dental students to attend dentist/physician communication training during the pre-clinical phase of studies is if they are planning to obtain a dual degree of dentistry and medicine. In that case, dual degree seekers have to attend courses and seminars in medical psychology and sociology in addition to their regular class load. One major concern of these seminars and courses and sociology is the teaching of successful patient-centered communication.

Within the context of the current amendment of study regulations at this medical school, the authors of this article argue that it is crucial that students of dentistry should also receive the opportunity to attend some type of training with a focus on communication early on during the pre-clinical part of dental studies. After all, the many benefits of a course curriculum that focuses on soft skills such as communication and self-awareness have been established in the past [15], and the current literature provides much information on the positive effect of structured communication training on dental students' communication skills [13, 16, 17]. Some courses may even have the potential to influence students' attitudes towards the subject [11].

Research also indicates that during the course of their studies, medical and dental students show an increase of psychosocial stress due to the demanding nature of the training [18-20]. In order to keep stress for students to a minimum during the pre-clinical phase of studies, a course in medical psychology with an emphasis on physician-patient communication was adapted on the notion that students could learn the content mostly in an experiential way. The goal was the assembly of a curriculum that would be structured, realistic and applicable, but first and foremost: very interactive. It was to provide a good complement to the more structured, lecture-style courses that make up the majority of preclinical studies. During this course, students were to have the opportunity to learn through experiment and experience, which raises the possibility of knowledge acquisition and retention during class and keeps study time outside of class to a minimum. Based on the results of previous research [11], it was hypothesized that by giving only brief theoretical input and then encouraging students to "simply give it a go" with actual hands-on exercise, an awareness of the importance of the subject (physician/patient-communication) could be developed, and student motivation towards the subject as well as student perception of its importance, influenced.

The focus of this study is a course of medical psychology and sociology for dual degree seekers which has been in place for two consecutive academic years (20142015) and consists of 20 teaching units, spread out over four sessions during two weekends. The course is offered three times during the academic year with an average group size of 12-14 students, and attending students are usually in their third semester of dental studies.

\section{Course curriculum development}

Student-centered teaching approaches have become increasingly common in medical education. For example, during problem-based learning (PBL) style courses, students are actively challenged to learn through engagement in real-world tasks and problems. This approach usually begins with the presentation of a medical problem for which students have to find a solution by using problem-solving strategies. Instructional guidance is kept to a minimum. Previous studies on this approach show that students very much appreciate the opportunity to work on "real" problems and that it facilitates acquisition of skills and ensures retention of knowledge [21]. A less investigated teaching approach is Experiential Learning theory (ELT). Just as PBL, ELT is a very interactive method of learning, and it is based on the premise that learning is the process of creating knowledge, and that during this process, the learner goes through the following four stages in a recursive process: experiencing, reflecting, thinking, and acting. Each stage is responsive to the individual learning situation and the content learned [22].

This course described in this article was adapted by two experts in the field of medical education based on the propositions of ELT. The goal was to design a flexible curriculum that could easily be adapted according to individual progress of each group and the overall pace of learning in which groups naturally differ. The specific course structure was then determined following the seven principles for efficient teaching by Hannah et al [11]. Table 1 illustrates these strategies and the way in which each one was incorporated into the curriculum.

The outcome was a structural blend of elements such as specific communication techniques, communication exercises with simulation patients (SP), analysis of video films, and exercises of (self-) awareness and (self-) perception. During the course, students were to not only practice their active listening skills at the example of medical history taking, but also to receive the chance for practical application during discussions, practical exercises, and group/team work. Stimulating communication among each other and with the instructor, paired with interesting content and cooperative learning structures were to motivate students to engage in a joint thinking and learning process, and thus promote multiple points of view. Content was to be delivered in a vivid and engaging way, so a high presence of cooperative methods such as group work, as well as activity-oriented methods such as simulation, role play, or case studies were included. These methods also allow for instructor and 
Table 1 Application of the seven teaching principals

\begin{tabular}{ll}
\hline Principal & Application \\
\hline $\begin{array}{l}\text { Use a skills-based approach, as opposed to an exclusively } \\
\text { didactic approach }\end{array}$ & $\begin{array}{l}\text { Exercises during which students were engaged and challenged directly } \\
\text { were included }\end{array}$ \\
Use clinically relevant scenarios & $\begin{array}{l}\text { Scenarios that were relevant to both, dentists and physicians } \\
\text { were included } \\
\text { Allow for self-assessment by students }\end{array}$ \\
$\begin{array}{l}\text { Students were encouraged to assess their own performance based } \\
\text { on videos filmed during exercises }\end{array}$ \\
Use videotaping method & $\begin{array}{l}\text { This method was used mainly for the purpose of self-reflection } \\
\text { and -assessment }\end{array}$ \\
$\begin{array}{ll}\text { Use simulated patients with expertise in a variety of clinical } \\
\text { roles and in the monitoring of student performance and }\end{array}$ & $\begin{array}{l}\text { Simulation patients were used specifically for feedback purposes and } \\
\text { the give students the opportunity to experiment with the various } \\
\text { communication techniques learned during the course }\end{array}$ \\
$\begin{array}{l}\text { Use an integrated teaching team comprising health sciences } \\
\text { staff and human sciences disciplines }\end{array}$ & $\begin{array}{l}\text { The course curriculum was developed by a team of medical and } \\
\text { psychological experts in the field of communication; however, the } \\
\text { course was taught by one person only, a psychologist }\end{array}$ \\
Ensure small groups for optimal student learning & Maximum group size was at 14 participants
\end{tabular}

peers to give feedback in a way that would directly influence the students need to be rewarded, and thus cause positive emotions and a feeling of accomplishment [23]. Direct frontal instructor input was restricted to the absolute minimum. Table 2 illustrates the main components of this course curriculum.

\section{Methods}

\section{Participants and procedure}

After having attended the last day of the course, all dental students $(N=81)$ who had participated were asked to fill out a survey which consisted of ten standardized Likert- scale items and two open questions. Students were given about 20 min to fill out the survey and were verbally encouraged to take time for adequate reflection on the individual questions.

\section{Survey}

Students had to rate ten items pertaining to the course they had attended in Likert type scale (Table 3). Additionally, two open questions asking students to name the aspects they liked about the course and also

Table 2 Curriculum - Communication training for dental students

\begin{tabular}{|c|c|c|c|}
\hline Subject & Learning objective(s) & $\begin{array}{l}\text { Instructional } \\
\text { methods }\end{array}$ & $\begin{array}{l}\text { Approximate time } \\
\text { spent on task } \\
\text { (in hours) }\end{array}$ \\
\hline Biopsychosocial Model & $\begin{array}{l}\text { Learn about the importance of communication } \\
\text { for successful physician-patient interaction and } \\
\text { the healing process }\end{array}$ & $\begin{array}{l}\text { Brief instructor input } \\
\text { Self-reflection } \\
\text { Group discussion }\end{array}$ & 2 \\
\hline $\begin{array}{l}\text { Communication techniques } \\
\text { and strategies }\end{array}$ & $\begin{array}{l}\text { Learn about and practice active listening at the } \\
\text { example of medical history taking }\end{array}$ & $\begin{array}{l}\text { Brief instructor input } \\
\text { Practical exercises } \\
\text { Practical exercise with SP }\end{array}$ & 4 \\
\hline $\begin{array}{l}\text { (Self-) awareness: external and } \\
\text { (self) perception }\end{array}$ & $\begin{array}{l}\text { Become aware of "self" } \\
\text { Understand the impact of internal subjectivity in one's } \\
\text { attitudes, values, and beliefs of reality } \\
\text { Recognize one's feelings during "easy" or "difficult" } \\
\text { patient-physician interactions }\end{array}$ & $\begin{array}{l}\text { Brief instructor input } \\
\text { Visual Thinking Strategy } \\
\text { Role play } \\
\text { Practical exercise with SP }\end{array}$ & 5 \\
\hline $\begin{array}{l}\text { Communicating empathy and } \\
\text { emotional awareness/understanding }\end{array}$ & $\begin{array}{l}\text { Learn how to use means of non-verbal communication } \\
\text { effectively } \\
\text { Understand the difference between feelings of sympathy } \\
\text { and feelings of empathy }\end{array}$ & $\begin{array}{l}\text { Brief instructor input } \\
\text { Video film analysis } \\
\text { Group discussion } \\
\text { Reflection }\end{array}$ & 3 \\
\hline Attitude, bias and emotion-handling & $\begin{array}{l}\text { Learn how personal attitudes, biases, fears, emotional reflexes, } \\
\text { psychosocial defenses, and moods can interfere with one's } \\
\text { ability to arrive at an accurate diagnosis, prescribe appropriate } \\
\text { treatment, and promote healing }\end{array}$ & $\begin{array}{l}\text { Brief instructor input } \\
\text { Prompting questions } \\
\text { Group discussion }\end{array}$ & 3 \\
\hline Personal development and well-being & $\begin{array}{l}\text { Become aware of the importance of personal development } \\
\text { and well-being } \\
\text { Recognize personal limits and learn when to seek support } \\
\text { and consultation }\end{array}$ & $\begin{array}{l}\text { Brief instructor input } \\
\text { Group discussion }\end{array}$ & 3 \\
\hline
\end{tabular}


Table 3 Survey results

\begin{tabular}{lll}
\hline Item & M & SD \\
\hline $\begin{array}{l}\text { 1.) How much interest did you have initially } \\
\text { to participate in the course? }\end{array}$ & 1.69 & .79 \\
$\begin{array}{l}\text { 2.) Did the course increase your interest } \\
\text { in the subject matter? }\end{array}$ & 1.46 & .79 \\
$\begin{array}{l}\text { 3.) Has the course helped you develop more } \\
\text { confidence in your communication skills? }\end{array}$ & 1.69 & .79 \\
$\begin{array}{l}\text { 4.) How helpful did you find the practical exercises? } \\
\text { 5.) How much have you learned about }\end{array}$ & 1.59 & .76 \\
patient-centered communication? & 1.68 & .83 \\
6.) How helpful did you find the exercises & & \\
with simulation patients? & 1.35 & .55 \\
7.) How relevant would you rate this course & & \\
for a later physician/dentist - patient interaction? & 1.65 & .79 \\
8.) Was the trainer sensitive to student needs and concerns? & 1.15 & .53 \\
$\begin{array}{l}\text { 9.) Was a good balance of student participation and } \\
\text { trainer contribution achieved? }\end{array}$ & 1.19 & .55 \\
$\begin{array}{l}\text { 10.) On a scale from } 1 \text { (very good) to } 5 \text { (very bad), } \\
\text { how would you rate the course overall? }\end{array}$ & 1.69 & .69 \\
\hline
\end{tabular}

Scale: 1 (very much) to 5 (not much at all); $M$ mean, SD standard deviation

the aspects they thought could be improved. Return rate of the survey was $100 \%$. Data were analyzed using SPSS statistics software. The open questions were evaluated according to qualitative content analysis and frequency analysis with the qualitative analysis software program MAXQDA [24].

\section{Results}

\section{Quantitative results}

The survey results in Table 3 show that many students reported that their initial interest in the course was due to the fact that it is a dual degree requirement.

However, later on students rated the course as highly important in terms of physician/dentist-patient interaction. Quantitative analysis revealed that many students already had an initial interest in the subject, but also that this interest had increased during or after the course. Students even considered the training of communication skills to be more important after they had attended the course than prior to it. Specific aspects of the curriculum course participants regarded as especially important were (self-) awareness and (self-) perception. The practice of communication skills with teacher-, peer- and SP feedback and a particular focus on self-perception and -awareness were valued highly by students because it provided a different learning experience in a curriculum that is sometimes perceived as rigid. Especially the opportunity to experiment with what has been learned, and time to practice in the safety of a simulated situation during role play and SP exercises were very much appreciated.

\section{Qualitative results}

Content analysis of the open questions showed that students experienced the course to be very applicable and useful in terms of a later dentist/physician-patient interaction (25 indications). One aspect that seemed to have left a positive impression was that the course was viewed as very interactive. The ratio between instructor input and active student participation was experienced as stimulating and within this context, the multitude of different teaching methods led students to feel especially involved with the course content. The opportunity to practice the various techniques introduced right away with simulation patients was named as very helpful because it allowed for experimentation, personal experience and reflection. Also, the importance of the role and qualities of the instructor became apparent. Frequently, the instructor was named crucial for the creation of a pleasant learning atmosphere and the perceived flexibility of the course. The subject of awareness was wellreceived, since according to students' comments in the qualitative section of the questionnaire, active reflection and self-analysis was barely possible anywhere else during pre-clinical studies. Especially the opportunity to readily try out what has been learned without worrying about negative judgment has been valued by course participants. Table 4 illustrates the frequency with which the indications have been made as well as the codes on the positive spectrum which have been constructed using an inductive approach [24].

Critique of the course was largely limited to organizational aspects. In the view of students, weekend courses pose an extra challenge in an already rigorous semester. Even with the course being an add-on to regular dental studies, some students wished that it would have been part of the regular curriculum. Some thought that the relevancy of the course would have been even higher during clinical studies, because it would have allowed for immediate practice with real patients. Some would have liked to

Table 4 Code system - positive spectrum

\begin{tabular}{ll}
\hline Code & Number of indications \\
\hline Applicability of course content & 25 \\
Interactive nature of the course & 23 \\
Variety of teaching methods & 19 \\
Instructor qualities & 16 \\
Course atmosphere & 16 \\
Course flexibility & 15 \\
Opportunity to practice with SP & 13 \\
\hline
\end{tabular}


have had more time for the individual exercises, especially for the ones with simulation patients. One major criticism was that because of time constraint not all students received the opportunity to practice with a simulation patient. Table 5 illustrates the coding of the negative spectrum.

\section{Discussion}

Previous research has demonstrated that medical students have positive attitudes towards learning and using communication skills [25-27] and within this context, experiential methods have been shown to be more effective in teaching communication skills than lecture methods $[11,12]$. The present study confirms previous findings by demonstrating that experiential learning activities allow students to apply abstract concepts in realistic patient-care scenario and that the use of experiential methods may help medical students to appreciate the importance of learning communication skills [11, 28, 29]. In the described course curriculum, brief theoretical elements were combined with a multitude of practical exercises. Through this active, social learning process, students received the possibility to explore their own concepts, attitudes and values. Even though some students appeared to have needed an initial phase of "warming-up" to the experiential approach, methods such as role play and simulation exercises with SP were evaluated positively because it provided them with feelings of competency, autonomy, and social inclusion; aspects that can cause students to act intrinsically as opposed to simply acting according to a standardized procedure [30]. Positive experience, identification, and the analysis of personal emotions are vital for learning and motivation so during the course, aspects of (self-) perception were emphasized. From the perspective of educational psychology, the practical exercises used during the course also increased the likelihood of reception and retention of new knowledge [22].

Overall, experiential learning seems to be a valid alternative to structured education based curricula. However, as a curriculum designer and as an instructor, one has to be willing to accept that this approach at times might be

Table $\mathbf{5}$ Code system - negative spectrum

\begin{tabular}{ll}
\hline Code & $\begin{array}{l}\text { Number of } \\
\text { indications }\end{array}$ \\
\hline Time frame of the course is too short & 23 \\
Weekend sessions are inconvenient & 19 \\
Course would fit better during clinical part of studies & 8 \\
Not everyone was able to practice with SP & 6 \\
Course is not part of the regular dental curriculum & 6 \\
Individually shorter, but more frequent sessions & 6 \\
\hline
\end{tabular}

flawed in a technical aspect, and that not all students are comfortable with the perceived lack of guidelines, but it does have the potential to awaken unknown motivation for the subject in students. In general, the present study showed that the subject of physician-patient communication is experienced by students as an important one. In particular, it was found that the experimentation with, and the reflection on the experience have been rated as particularly helpful by students and also had a positive influence on their attitude towards the subject.

\section{Conclusion}

In the fields of dentistry and medicine, knowledge and technical skills are not sole determinants of good practice. Active listening skills, gathering and communicating information effectively, handling patient emotions sensitively, demonstrating empathy, and awareness are also crucial aspects. In this study, it has been demonstrated that an experiential learning approach can be used to motivate students, influence their perception of the subject of communication, and provide opportunity for selfreflection and awareness. Thus, dental students should be given the opportunity to learn about, experiment with, and reflect on their communication strategies early on during their studies, so that they may be able to successfully communicate with patients later on.

\section{Abbreviations}

ELT: Experiential Learning Theory; SP: Simulated patient

\section{Acknowledgements}

Not applicable.

\section{Funding}

We acknowledge financial support by Deutsche Forschungsgemeinschaft and Ruprecht-Karls-Universität Heidelberg within the funding program Open Access Publishing

Availability of data and materials

The datasets generated and analyzed during the current study are not publicly available due to protecting participant confidentiality but are available from the corresponding author upon reasonable request.

\section{Authors' contributions}

SA and JHS jointly developed the course content and the research idea. SA searched literature, conducted data analyses and prepared the manuscript. Both authors read and approved the final manuscript.

Ethics approval and consent to participate

All research has been conducted in accordance with the Declaration of Helsinki and need for approval has been waived by the ethics committee of the Medical Faculty of Heidelberg University. The need for consent to participate was waived by the ethics committee of the Medical Faculty of Heidelberg University.

Consent for publication

Not applicable.

Competing interests

The authors declare that they have no competing interests. 


\section{Publisher's Note}

Springer Nature remains neutral with regard to jurisdictional claims in published maps and institutional affiliations.

Received: 19 June 2017 Accepted: 20 March 2018

Published online: 27 March 2018

\section{References}

1. Griffin SJ, Kinmonth AL, Veltman MW, Gillard S, Grant J, Stewart M. Effect on health-related outcomes of interventions to alter the interaction between patients and practitioners: a systematic review of trials. Ann Fam Med. 2004;2:595-608.

2. Levinson W, Lesser CS, Epstein RM. Developing physician communication skills for patient-centered care. Health Aff (Millwood). 2010;29:1310-8.

3. Rouse RA, Hamilton MA. Dentists' technical competence, communication, and personality as predictors of dental patient anxiety. J Behav Med. 1990; 13:307-19.

4. Sondell K, Soderfeldt B. Dentist-patient communication: a review of relevant models. Acta Odontol Scand. 1997;55:116-26.

5. Yamalik N. Dentist-patient relationship and quality care 3. Communication. Int Dent J. 2005:55:254-6.

6. Carey JA, Madill A, Manogue M. Communications skills in dental education: a systematic research review. Eur J Dent Educ. 2010;14:69-78.

7. Woelber J, Deimling D, Langenbach D, Ratka-Krueger P. The importance of teaching communication in dental education. A survey amongst dentists, students and patients. Eur J Dent Educ. 2012;16:e200-e4.

8. Anderson R. Patient expectations of emergency dental services: a qualitative interview study. Br Dent J. 2004;197:331-4.

9. Zolnierek KB, Dimatteo MR. Physician communication and patient adherence to treatment: a meta-analysis. Med Care. 2009:47:826-34.

10. Fischer M, Bauer D, Mohn K. Finally finished! National competence based catalogues of learning objectives for undergraduate medical education (NKLM) and dental education (NKLZ) ready for trial. GMS J Med Educ. 2015;32(3): Doc35. https://doi.org/10.3205/zma000977.

11. Hannah A, Millichamp CJ, Ayers KM. A communication skills course for undergraduate dental students. J Dent Educ. 2004;68:970-7.

12. Aspegren K. BEME guide no. 2: teaching and learning communication skills in medicine-a review with quality grading of articles. Med Teach. 1999;21:563-70.

13. Rüttermann S, Sobotta A, Hahn P, Kiessling C, Härtl A. Teaching and assessment of communication skills in undergraduate dental education-a survey in German-speaking countries. Eur J Dent Educ. 2017;21:151-8.

14. Schultz J-H, Schönemann J, Lauber H, Nikendei C, Herzog W, Jünger J. Einsatz von Simulationspatienten im Kommunikations-und Interaktionstraining für Medizinerinnen und Mediziner (Medi-KIT): Bedarfsanalyse-Training-Perspektiven. Gruppe Interaktion Organisation Zeitschrift für Angewandte Organisationspsychologie (GIO). 2007;38:7-23.

15. Kalenderian E, Skoulas A, Timothe P, Friedland B. Integrating leadership into a practice management curriculum for dental students. J Dent Educ. 2010; 74:464-71.

16. Haak R, Rosenbohm J, Koerfer A, Obliers R, Wicht MJ. The effect of undergraduate education in communication skills: a randomised controlled clinical trial. Eur J Dent Educ. 2008;12:213-8.

17. Bachmann C, Kiessling C, Härtl A, Haak R. Communication in health professions: a European consensus on inter-and multi-professional learning objectives in German. GMS J Med Educ. 2016;33(2): Doc23. https://doi.org/ 10.3205/zma001022

18. Elani HW, Allison PJ, Kumar RA, Mancini L, Lambrou A, Bedos C. A systematic review of stress in dental students. J Dent Edu. 2014;78:226-42.

19. Ahmad MS, Md Yusoff MM, Abdul Razak I. Stress and its relief among undergraduate dental students in Malaysia. Southeast Asian J Trop Med Public Health. 2011:42:996-1004.

20. Alzahem AM, van der Molen HT, Alaujan AH, Schmidt HG, Zamakhshary MH. Stress amongst dental students: a systematic review. Eur J Dent Educ. 2011; 15:8-18.

21. Barrows HS. A taxonomy of problem-based learning methods. Med Educ. 1986:20:481-6.

22. Kolb DA. Experiential learning: experience as the source of learning and development. Englewood Cliffs: Prentice Hall. 2014

23. Mega C, Ronconi L, De Beni R. What makes a good student? How emotions, self-regulated learning, and motivation contribute to academic achievement. J Educ Psychol. 2014;106:121.
24. Mayring P. Qualitative content analysis: theoretical foundation, basic procedures and software solution. Klagenfurt; 2014. http://nbn-resolving.de/ urn:nbn:de:0168-ssoar-395173.

25. Anvik T, Grimstad H, Baerheim A, Bernt Fasmer O, Gude T, Hjortdahl P, Holen A, Risberg T, Vaglum P. Medical students' cognitive and affective attitudes towards learning and using communication skills-a nationwide cross-sectional study. Med Teach. 2008;30:272-9.

26. Kalenderian E, Taichman RS, Skoulas A, Nadershahi N, Victoroff KZ. Developing the next generation of leaders in oral health. J Dent Educ. 2013;77:1508-14.

27. Skoulas A, Kalenderian E. Leadership training for postdoctoral dental students. J Dent Educ. 2012;76:1156-66.

28. Adamson KA. Piloting a method for comparing two experiential teaching strategies. Clin Simul Nurs. 2012;8:e375-e82.

29. Kalenderian E, Maramaldi P, Kinnunen TH, Spinell D, Nelson LP. Assessing early performance in the patient-doctor relationship in dental education. J Dent Educ. 2012;76:159-67.

30. Koponen J, Pyorala E, Isotalus P. Comparing three experiential learning methods and their effect on medical students' attitudes to learning communication skills. Med Teach. 2012;34:e198-207.

\section{Submit your next manuscript to BioMed Central and we will help you at every step:}

- We accept pre-submission inquiries

- Our selector tool helps you to find the most relevant journal

- We provide round the clock customer support

- Convenient online submission

- Thorough peer review

- Inclusion in PubMed and all major indexing services

- Maximum visibility for your research

Submit your manuscript at www.biomedcentral.com/submit 